\title{
The Effects of Budesonid that Added to Tiotropium Therapy on Health Related Quality of Life, Exercise Capacity and Pulmonary Functions in COPD Patients
}

\author{
Bahar Arslan ${ }^{1}$, Teyfik Turgut ${ }^{2}$ \\ ${ }^{1}$ Clinic of Chest Diseases, Kayseri Training and Research Hospital, Kayseri \\ ${ }^{2}$ Department of Chest Diseases, Firat University Faculty of Medicine, Elazı̆̆
}

\begin{abstract}
Objective: The aim of this study was to evaluate the effects of adding inhaled budesonide to the tiotropium treatment on the pulmonary function tests, health-related quality of life and exercise capacity of patients with chronic obstructive pulmonary disease (COPD).

Methods: Forty study subjects with COPD were randomized to two groups. The patients in the first group was treated with $1 \times 118$ mcg of Tiotropium and the patients in the second group was treated with the combination of tiotropium (18 mcg lxl) and budesonide (400 mcg 2xl) for three months. Pulmonary function tests, six minute walk test, body mass index and Saint George Respiratory Questionnaire (SGRQ) scores were recorded both at the beginning and 3 months later and the results at the begining and third month were compared with each other. There were no statistically significant difference in all basline parameters between the two groups.

Results: At the end of the study, no statistically significant differences were obtained between two groups in terms of pulmonary function tests $(p>0.05)$. Significant improvements were observed on the parameters of walking distance $(p=0.023)$ and SGRQ scores (symptom score: $\mathrm{p}<0.001$, activity score: $\mathrm{p}=0.001$, impact score: $\mathrm{p}=0.003$ and total score: $\mathrm{p}<0.001)$ in Group 2 when compared with Group 1 .
\end{abstract}

Conclusion: These results show that, in patients with COPD, tiotropium/budesonide combination is more effective than alone tiotropium inhalation in quality of life and exercise performance. But this combination is not more effective in improving lung functions.

Keywords: Budesonide, chronic obstructive pulmonary disease, exercise capacity, quality of life questionnaire, tiotropium

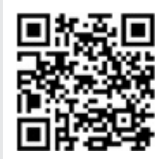

Received Date: 14.11.2014 Accepted Date: 24.06 .2015 Available Online Date: 09.11 .2015 DOI: 10.5152/ejp.2015.21939

Corresponding Author Teyfik Turgut

E-mail: teyfikt@gmail.com

-Available online at www.eurasianjpulmonol.com 4.0 International License.

\section{INTRODUCTION}

Chronic obstructive pulmonary disease (COPD) is a disorder that does not demonstrate complete reversibility and that is characterized by limited air flow. It mainly presents with a chronic inflammatory response given by the lungs to harmful particles and gases. Chronic inflammation causes "remodeling" and obstruction in the airways. Inflammation and its outcomes can be seen in all tissues of the lungs, and it also demonstrates systemic features $(1,2)$.

It has been found that in patients with COPD, regular treatment with inhaled corticosteroids does not change forced expiratory volume in 1 second $\left(\mathrm{FEV}_{1}\right)$ loss; however, it decreases the frequency of attacks and leads to improvement in the health condition of COPD patients with low FEV , and $^{2}$ recurrent exacerbations. On the other hand, long-acting bronchodilators are recommended to all patients at Stage 2 (1). Previous studies revealed that tiotropium, a long-acting bronchodilator, affected FEV 1 values more positively than a placebo or ipratropium and decreased the number of attacks (3-6). Recently, the number of large studies conducted with long-acting $\beta_{2}$ agonist+inhaled corticosteroid combinations has increased. However, there are a few studies on the effects of long-acting anticholinergic+inhaled corticosteroid combinations on the pulmonary functions, exercise capacity, and quality of life of this patient group.

In our study, the efficiency of inhaled budesonide that was added to long-acting anticholinergic therapy used in COPD patients was evaluated through a quality of life questionnaire and exercise 
capacity examinations in addition to spirometric examinations. The most detailed and standardized questionnaire used for COPD is St. George's Respiratory Questionnaire (SGRQ). This questionnaire is also used to determine the effects of many drugs on the quality of life (7). One of the exercise tests, which is easy to use, is the 6 -min walk test (6MWT). There is a significant correlation between walking distance and survival rate. The 6-min walk test is commonly used, particularly for evaluating the effects of pulmonary rehabilitation (8).

In this study, we aimed to investigate the effects of inhaled budesonide therapy in addition to tiotropium, which is a long-acting bronchodilator used in COPD patients, on the quality of life, exercise capacity, and respiratory function of patients.

\section{METHODS}

\section{Patient Selection}

Forty patients who were followed up for Stage 3-4 COPD, diagnosed according to the GOLD guideline, at Firat University Medical Faculty, Department of Thoracic Diseases, who were in a stable state for the previous 6 weeks, and who did not have respiratory tract infections or acute COPD attacks during this period, were included in the study. On the other hand, patients who had a history of asthma diagnosis, atopy, and peripheral blood eosinophilia $\left(\geq 600 / \mathrm{mm}^{3}\right)$, recent myocardial infarction (Ml), heart failure, known symptomatic prostatic hypertrophy, and narrow-angle glaucoma and who developed an additional disease apart from COPD during the study were excluded from the study.

At the beginning, the drugs that the patients had previously used were noted. Theophylline, inhaled anticholinergics and/or long-acting $\beta$ agonists were discontinued $48 \mathrm{~h}$ before the study, short-acting inhaled $\beta_{2}$ agonists were stopped $12 \mathrm{~h}$ before, and inhaled steroids were stopped 2 weeks before.

Patients who did not tolerate a discontinuance of inhaled drugs were excluded from the study. During the study period, patients were permitted to use rescue drugs. Patients complying with the study requirements were divided into two groups with a simple randomization method. Each patient was included in Group 1 or Group 2 according to the application sequence. The first group (Group 1) was administered tiotropium inhaler capsule $18 \mathrm{mcg}$ (Spiriva Inhaler Capsule; Boehringer Ingelheim, Ingelheim, Germany) once a day. The second group (Group 2) was administered budesonide inhaler capsule 400 mcg (Miflonide 400 mcg inhaler capsule; Novartis, Basel, Switzerland) in the morning and evening, in addition to tiotropium inhaler capsule $18 \mathrm{mcg}$ once a day. Each patient in the study was followed up for 3 months.

For all cases, detailed pulmonary function tests (PFT) and maximum inspiratory and maximum expiratory pressures (MIP and MEP) were measured at the beginning and at the end of the third month. Pulmonary function tests was initially performed at least $24 \mathrm{~h}$ after the use of a long-acting bronchodilator and at least $6 \mathrm{~h}$ after the use of short-acting bronchodilators between 8:00 a.m. and 10:00 a.m. At the end of the third month, PFT was performed $24 \mathrm{~h}$ after the previous dose of tiotropium and at least $6 \mathrm{~h}$ after using short-term bronchodilators if the patient had used a rescue drug. Moreover, a quality of life questionnaire was applied and exercising capacities were evaluated.

\section{Measurement of Pulmonary Function Tests}

Pulmonary function tests was conducted with a pulmonary function test device (Medgraphics Ultima series CPX 790705-209; MGC Diagnostics Corporation, Saint Paul, MN, USA) in our clinic using nose clips at room temperature and in the sitting position. Of the routine tests, $\mathrm{FEV}_{1}$, forced vital capacity (FVC) values, and $\mathrm{FEV}_{1} / \mathrm{FVC}$ ratio were measured and recorded. At least three measurements were made and the best results were evaluated. The data were interpreted in accordance with the estimated values of the European Respiratory Society (9).

Lung volumes were measured by body plethysmograph (Medgraphics, Elite SeriesTm Plethysmograph; MGC Diagnostics Corporation, Saint Paul, MN, USA). The residual volume (RV), resistance of airway (RAW), and MIP and MEP values were recorded. The MIP value was measured at least five times at the level of RV and the best three values were recorded (10-12).

Table 1. Study groups' demographic features, baseline spirometry, quality of life, exercise capacity, and FFM values

\begin{tabular}{|c|c|c|}
\hline & Group 1 & Group 2 \\
\hline Number of patients & 16 & 20 \\
\hline Age of patient (years) & $62.62 \pm 7.05$ & $63.75 \pm 10.13$ \\
\hline Gender (M/F) & $14 / 2$ & $16 / 4$ \\
\hline Duration of COPD (years) & 4.8 & 5.1 \\
\hline Present/past smoking history & $4 / 12$ & $6 / 14$ \\
\hline Cigarettes (packs.year) & $25.64 \pm 6.54$ & $26.55 \pm 5.94$ \\
\hline $\mathrm{FEV}_{1}(\mathrm{~L})$ & $1.40 \pm 0.23$ & $1.21 \pm 0.30$ \\
\hline $\mathrm{FEV}_{1}(\%)$ & $43.18 \pm 4.83$ & $41.90 \pm 7.52$ \\
\hline FVC (\%) & $68.75 \pm 7.83$ & $61.70 \pm 13.62$ \\
\hline $\mathrm{FEV}_{1} / \mathrm{FVC}$ & $55.87 \pm 8.13$ & $54.10 \pm 8.33$ \\
\hline RV (\%) & $197.56 \pm 49.75$ & $226.00 \pm 58.26$ \\
\hline TLC (\%) & $119.06 \pm 16.92$ & $128.10 \pm 25.67$ \\
\hline Raw (\%) & $188.81 \pm 102.21$ & $224.25 \pm 113.92$ \\
\hline $\mathrm{MIP}\left(\mathrm{cmH}_{2} \mathrm{O}\right)$ & $-60.43 \pm 20.60$ & $-62.90 \pm 17.80$ \\
\hline $\operatorname{MEP}\left(\mathrm{cmH}_{2} \mathrm{O}\right)$ & $71.56 \pm 20.18$ & $67.65 \pm 19.95$ \\
\hline \multicolumn{3}{|l|}{ SGRQ } \\
\hline Symptom score & $52.31 \pm 16.20$ & $59.75 \pm 17.27$ \\
\hline Activity score & $59.64 \pm 18.62$ & $71.46 \pm 19.39$ \\
\hline Impact score & $40.95 \pm 9.78$ & $50.43 \pm 19.64$ \\
\hline Total score & $48.92 \pm 9.00$ & $58.27 \pm 17.29$ \\
\hline $6 \mathrm{MWT}(\mathrm{m})$ & $411.68 \pm 79.92$ & $406.35 \pm 86.61$ \\
\hline FFM (kg) & $56.18 \pm 5.69$ & $53.19 \pm 7.57$ \\
\hline
\end{tabular}

For all parameters $\mathrm{p}>0.05$

Values are presented as mean $\pm \mathrm{SD}$.

COPD: Chronic obstructive pulmonary disease; $\mathrm{FEV}_{1}$ : forced expiratory volume in1 s; FFM: fat free body mass; FVC: forced vital capacity; MEP: maximal expiratory pressure; MIP: maximal inspiratory pressure; Raw: resistance of airway; RV: residual volume; SGRQ: St. George's Respiratory Questionnaire; TLC: total lung capacity; 6MWT: 6-min walk test 


\section{Measurement of Fat-Free Mass}

Fat-free mass (FFM) was measured via a single-frequency $(50 \mathrm{kHz})$ bioelectrical impedance analyzer (Tanita Body Composition Analyzer, model TBF 300; Tanita Corporation, Tokyo, Japan).

\section{Evaluation of the Quality of Life}

The quality of life was evaluated with the Turkish version of SGRQ. The questionnaire, consisting of 76 questions, was applied by means of an interview and the symptom, impact, activity, and total scores were calculated through the formulas in the explanation of the test (13).

\section{Measurement of Exercise Capacity}

Exercise capacity was evaluated with $6 \mathrm{MWT}$, which was performed by evaluating dyspnea and leg fatigue according to the BORG scale and heart rate per minute on a $30 \mathrm{~m}$ long indoor flat surface (by marking each 3 meters). At the end of 6 meters, the total distance that was walked was recorded in meters. The criteria of the American Thoracic Society were taken into consideration for testing (14).

All cases were informed about the inhalation techniques, and their written informed consent was obtained. Ethical approval for the study was received from the Ethics Committee of Firat University.

\section{Statistical Analysis}

The obtained data were statistically analyzed using the Statistical Package for Social Sciences (SPSS) ver. 15.0 (SPSS Inc.; Chicago, IL,

Table 2. Spirometry, quality of life, exercise capacity, and FFM values of study groups at the end of the $3^{\text {rd }}$ month

\begin{tabular}{|c|c|c|}
\hline & Group 1 & Group 2 \\
\hline $\mathrm{FEV}_{1}(\mathrm{~L})$ & $1.49 \pm 0.31$ & $1.32 \pm 0.37$ \\
\hline $\mathrm{FEV}_{1}(\%)$ & $48.43 \pm 8.89$ & $47.20 \pm 13.14$ \\
\hline FVC (\%) & $67.12 \pm 13.18$ & $61.35 \pm 15.19$ \\
\hline $\mathrm{FEV}_{1} / \mathrm{FVC}$ & $58.75 \pm 7.97$ & $56.00 \pm 6.96$ \\
\hline RV (\%) & $191.81 \pm 47.08$ & $219.65 \pm 40.86$ \\
\hline TLC (\%) & $118.06 \pm 19.29$ & $121.95 \pm 19.25$ \\
\hline Raw (\%) & $137.75 \pm 70.74$ & $178.65 \pm 97.46$ \\
\hline $\mathrm{MIP}\left(\mathrm{cmH}_{2} \mathrm{O}\right)$ & $-58.31 \pm 19.56$ & $-55.50 \pm 18.79$ \\
\hline $\operatorname{MEP}\left(\mathrm{cmH}_{2} \mathrm{O}\right)$ & $69.93 \pm 20.06$ & $64.45 \pm 19.11$ \\
\hline \multicolumn{3}{|l|}{ SGRQ } \\
\hline Symptom score & $56.24 \pm 18.24$ & $54.46 \pm 17.25$ \\
\hline Activity score & $63.10 \pm 18.77$ & $64.36 \pm 18.59$ \\
\hline Impact score & $45.09 \pm 10.49$ & $42.89 \pm 15.77$ \\
\hline Total score & $48.92 \pm 9.00$ & $58.27 \pm 17.29$ \\
\hline 6MWT (m) & $403.18 \pm 69.73$ & $429.45 \pm 83.97$ \\
\hline FFM (kg) & $55.98 \pm 6.00$ & $53.53 \pm 5.68$ \\
\hline \multicolumn{3}{|c|}{ For all parameters $p>0.05$} \\
\hline \multicolumn{3}{|c|}{ Values are presented as mean \pm SD. } \\
\hline \multicolumn{3}{|c|}{$\begin{array}{l}\text { COPD: Chronic obstructive pulmonary disease; FEV } \text { forced expiratory volume }_{\text {in } 1 \mathrm{~S} \text {; FFM: fat free body mass; FVC: forced vital capacity; MEP: maximal }} \text { in } \\
\text { expiratory pressure; MIP: maximal inspiratory pressure; Raw: resistance of } \\
\text { airway; RV: residual volume; SGRQ: St. George's Respiratory Questionnaire; TLC: } \\
\text { total lung capacity; 6MWT: 6-min walk test }\end{array}$} \\
\hline
\end{tabular}

USA) software. The Mann-Whitney $U$ test was used for statistical comparison of the groups, and the Wilcoxon test was used for comparing intra-group baseline values and the values obtained the end of the third month. Moreover, the chi-square test was employed for comparing data such as gender and history of smoking between groups. The data obtained were presented as mean \pm standard deviation. A value of $p<0.05$ was accepted to be statistically significant.

\section{RESULTS}

A total of 40 patients from both groups were included in the study. Some patients in Group 1 were excluded from the study (one for having an attack in the control period and three for not coming for the control period). The demographic features, baseline spirometry, respiratory muscle strength, quality of life, exercising capacity, and FFM values of the patients that completed the study are presented in Table 1. No statistically significant difference was found between the baseline values of both groups in terms of all parameters.

Both groups included in the study were re-evaluated with respect to pulmonary functions and other parameters after being followed up for 3 months; no statistically significant difference was observed between the two groups in terms of all parameters (Table 2).

When each group was evaluated in itself with respect to the values obtained at the beginning and at the end of the study, it was detected that the FEV ${ }_{1}$ (as both liter and expected value percentage)

Table 3. Spirometry, quality of life, exercise capacity, and FFM values obtained at the beginning and at the end of the study in Group 1

\begin{tabular}{|c|c|c|c|}
\hline & Baseline & $3^{\text {rd }}$ month & p \\
\hline $\mathrm{FEV}_{1}(\mathrm{~L})$ & $1.40 \pm 0.23$ & $1.49 \pm 0.31$ & 0.010 \\
\hline $\mathrm{FEV}_{1}(\%)$ & $43.18 \pm 4.83$ & $48.43 \pm 8.89$ & 0.006 \\
\hline FVC (\%) & $68.75 \pm 7.83$ & $67.12 \pm 13.18$ & $>0.05$ \\
\hline $\mathrm{FEV}_{1} / \mathrm{FVC}$ & $55.87 \pm 8.13$ & $58.75 \pm 7.97$ & 0.024 \\
\hline RV (\%) & $197.56 \pm 49.75$ & $191.81 \pm 47.08$ & $>0.05$ \\
\hline TLC (\%) & $119.06 \pm 16.92$ & $118.06 \pm 19.29$ & $>0.05$ \\
\hline Raw (\%) & $188.81 \pm 102.21$ & $137.75 \pm 70.74$ & $>0.05$ \\
\hline $\operatorname{MIP}\left(\mathrm{cmH}_{2} \mathrm{O}\right)$ & $-60.43 \pm 20.60$ & $-58.31 \pm 19.56$ & $>0.05$ \\
\hline $\mathrm{MEP}\left(\mathrm{cmH}_{2} \mathrm{O}\right)$ & $71.56 \pm 20.18$ & $69.93 \pm 20.06$ & $>0.05$ \\
\hline \multicolumn{4}{|l|}{ SGRQ } \\
\hline Symptom score & $52.31 \pm 16.20$ & $56.24 \pm 18.245$ & $>0.0$ \\
\hline Activity score & $59.64 \pm 18.62$ & $63.10 \pm 18.77$ & $>0.05$ \\
\hline Impact score & $40.95 \pm 9.78$ & $45.09 \pm 10.49$ & $>0.05$ \\
\hline Total score & $48.92 \pm 9.00$ & $51.90 \pm 11.04$ & $>0.05$ \\
\hline $6 \mathrm{MWT}(\mathrm{m})$ & $411.68 \pm 79.92$ & $403.18 \pm 69.73$ & $>0.05$ \\
\hline FFM (kg) & $56.18 \pm 5.69$ & $55.98 \pm 6.00$ & $>0.05$ \\
\hline \multicolumn{4}{|c|}{ For all parameters $p>0.05$} \\
\hline \multicolumn{4}{|c|}{ Values are presented as mean \pm SD. } \\
\hline \multicolumn{4}{|c|}{$\begin{array}{l}\text { COPD: Chronic obstructive pulmonary disease; } F_{1} \text { : forced expiratory volume } \\
\text { in } 1 \mathrm{~s} \text {; FFM: fat free body mass; FVC: forced vital capacity; MEP: maximal } \\
\text { expiratory pressure; MIP: maximal inspiratory pressure; Raw: resistance of } \\
\text { airway; RV: residual volume; SGRQ: St. George's Respiratory Questionnaire; TLC: } \\
\text { total lung capacity; } 6 \mathrm{MWT:} \mathrm{6-min} \mathrm{walk} \mathrm{test}\end{array}$} \\
\hline
\end{tabular}


Table 4. Spirometry, quality of life, exercise capacity, and FFM values obtained at the beginning and at the end of the study in Group 2

\begin{tabular}{|c|c|c|c|}
\hline & Baseline & $3^{\text {rd }}$ month & p \\
\hline $\mathrm{FEV}_{1}(\mathrm{~L})$ & $1.21 \pm 0.30$ & $1.32 \pm 0.37$ & 0.040 \\
\hline $\mathrm{FEV}_{1}(\%)$ & $41.90 \pm 7.52$ & $47.20 \pm 13.14$ & 0.015 \\
\hline FVC (\%) & $61.70 \pm 13.62$ & $61.35 \pm 15.19$ & $>0.05$ \\
\hline $\mathrm{FEV}_{1} / \mathrm{FVC}$ & $54.10 \pm 8.33$ & $56.00 \pm 6.96$ & $>0.05$ \\
\hline RV (\%) & $226.00 \pm 58.26$ & $219.65 \pm 40.86$ & $>0.05$ \\
\hline TLC (\%) & $128.10 \pm 25.67$ & $121.95 \pm 19.25$ & $>0.05$ \\
\hline Raw (\%) & $224.25 \pm 113.92$ & $178.65 \pm 97.46$ & $>0.05$ \\
\hline $\mathrm{MIP}\left(\mathrm{cmH}_{2} \mathrm{O}\right)$ & $-62.90 \pm 17.80$ & $-55.50 \pm 18.79$ & $>0.05$ \\
\hline $\mathrm{MEP}\left(\mathrm{cmH}_{2} \mathrm{O}\right)$ & $67.65 \pm 19.95$ & $64.45 \pm 19.11$ & $>0.05$ \\
\hline \multicolumn{4}{|l|}{ SGRQ } \\
\hline Symptom score & $59.75 \pm 17.27$ & $54.46 \pm 17.25$ & 0.009 \\
\hline Activity score & $71.46 \pm 19.39$ & $64.36 \pm 18.59$ & 0.002 \\
\hline Impact score & $50.43 \pm 19.64$ & $42.89 \pm 15.77$ & 0.001 \\
\hline Total score & $58.27 \pm 17.29$ & $52.02 \pm 15.59$ & 0.001 \\
\hline 6MWT (m) & $406.35 \pm 86.61$ & $429.45 \pm 83.97$ & 0.005 \\
\hline FFM (kg) & $53.19 \pm 7.57$ & $53.53 \pm 5.68$ & $>0.05$ \\
\hline \multicolumn{4}{|c|}{ For all parameters $p>0.05$} \\
\hline \multicolumn{4}{|c|}{ Values are presented as mean $\pm \mathrm{SD}$. } \\
\hline \multicolumn{4}{|c|}{$\begin{array}{l}\text { COPD: Chronic obstructive pulmonary disease; FEV } \text { : forced expiratory volume } \\
\text { in } 1 \mathrm{~S} \text {; FFM: fat free body mass; FVC: forced vital capacity; MEP: maximal } \\
\text { expiratory pressure; MIP: maximal inspiratory pressure; Raw: resistance of } \\
\text { airway; RV: residual volume; SGRQ: St. George's Respiratory Questionnaire; TLC: } \\
\text { total lung capacity; } 6 \mathrm{MWT} \text { : 6-min walk test }\end{array}$} \\
\hline
\end{tabular}

and $\mathrm{FEV}_{1} / \mathrm{FVC}$ values in Group 1 were higher at the end of the third month than the baseline values $(p=0.010, p=0.006$, and $p=0.024$, respectively). On the other hand, no statistically significant difference was found for the other parameters (Table 3 ).

In Group 2, although a significant increase was found only in liter and expected $\%$ values of $\mathrm{FEV}_{1}(\mathrm{p}=0.040$ and $\mathrm{p}=0.015$, respectively), no change was detected in the other measurements (Table 4). Furthermore, different from Group 1, significant changes were observed in the 6MWT distances $(p=0.005)$ and SGRQ scores in Group $2(p=0.009$ for symptom score, $p=0.001$ for impact score, $p=0.002$ for activity score, and $p=0.001$ for total score).

Considering the differences between the values obtained at the beginning and at the end of the study, it was detected that although the quality of life questionnaire scores decreased in Group 2, they increased in Group 1, and the difference between them was statistically significant $(p=0.009$ for symptom score and $p=0.001$ for activity, impact, and total scores). In Group 1, there was a decrease of 5.37 $\mathrm{m}$ on average in the 6MWT, but in Group 2, there was an increase of $23.1 \mathrm{~m}$ on average. The difference between these data was statistically significant $(p=0.018)$ (Figures 1,2$)$. Although an increase was detected in the FEV values as liter and expected percentage in both groups, there was no statistically significant difference between the groups in terms of the mean increase ( $p>0.05)$.

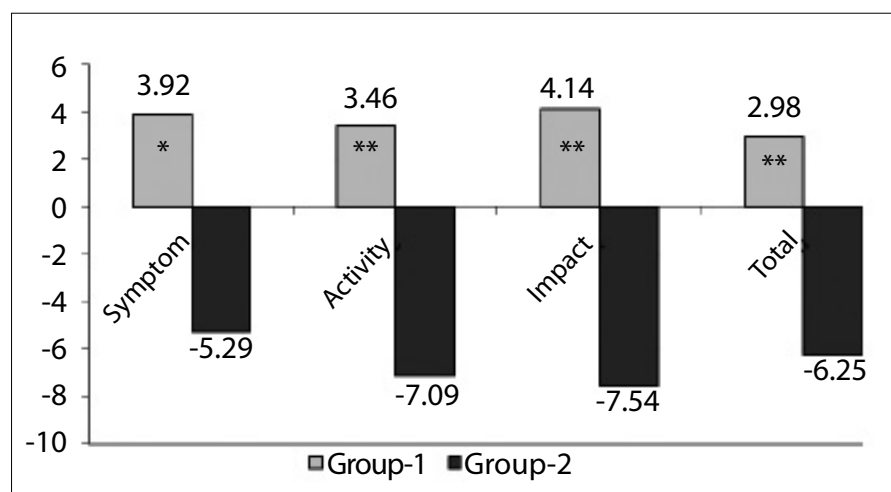

Figure 1. Changes in St. George's Respiratory Questionnaire (SGRQ) in both study groups $\left({ }^{*}: p=0.009,{ }^{* *}: p=0.001\right.$, data labels reflect the mean changes)

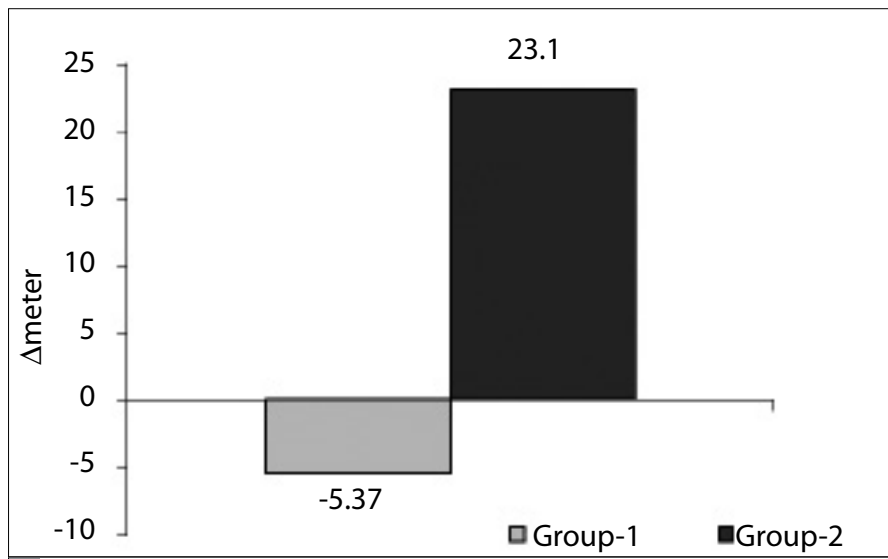

Figure 2. Changes in the values of walking distance obtained as a result of the 6-min walk test (6MWT) in both study groups ( $\Delta$ meter) $(p=0.018$, data labels reflect the mean changes)

\section{DISCUSSION}

It is known that airway inflammation plays a role in the pathogenesis of chronic obstructive pulmonary disease. Therefore, it is aimed to treat this early inflammation in the airways via anti-inflammatory agents and to prevent the progression of disease. Recently, researchers have tried to shed light on this issue through studies conducted regarding the role of inhaled steroids in COPD treatment. In the study we performed for this purpose, it was observed that the addition of inhaled steroids to routine bronchodilator treatment did not affect pulmonary functions, but had positive effects on exercise capacity, and the quality of life.

It has been revealed in many studies that inhaled tiotropium is effective in improving lung functions and the quality of life in patients with COPD compared with a placebo (15). Moreover, according to the results of many studies, tiotropium shows an equivalent effect with long-acting $\beta_{2}$ agonists in many parameters, such as the rates of hospitalization and pulmonary functions and the improvement of symptoms in COPD treatment (16).

Many studies investigating the effects of inhaled corticosteroids on airway obstruction in these patients have been conducted. The results obtained from these studies are contradictory. Although some studies revealed positive effects of inhaled corticosteroids on pulmo- 
nary functions, some revealed them to be ineffective. However, it was suggested in some studies that the inclusion of COPD patients with asthmatic features such as airway reversibility and allergies could contribute to this early response (17-22).

Studies including large series have recently been conducted on short- and long-term uses of inhaled steroids in stable COPD treatment. Although it was observed in EUROSCOP and Copenhagen studies that inhaled steroids did not affect FEV 1 loss, the EUROSCOP study revealed a significant superiority of the budesonide group in the evaluation of the quality of life. However, no statistically significant difference was found between the two groups with respect to exacerbations $(23,24)$. Moreover, the effects of inhaled fluticasone propionate on the pulmonary functions, exacerbation, and quality of life were investigated in moderate-severe COPD in an ISOLDE study; compared with the placebo group, it was demonstrated that the decrease in $\mathrm{FEV}_{1}$ was lower by a rate of $32 \%$ and was higher in the first 3 months. In more severe cases, there was a decrease in exacerbations at the rate of $25 \%$, which was particularly more apparent in the first year, the number of hospitalizations also decreased, and an increase in the quality of life was observed (25).

In another large-scale study, TORCH, it was shown that the use of fluticasone propionate alone or in combination with salmeterol decreased annual FEV 1 loss (26). In our study, the addition of inhaled steroids to bronchodilator treatment provided no additional benefit to respiratory functions. As stated above, in the results of previous studies examining the effects of inhaled steroids on the pulmonary functions of COPD patients, there are some contradictions. This might have resulted from dissimilarities between the patient groups. Moreover, in our study, the follow up periods of the patients were limited to 3 months.

In the literature, no studies examining the direct effects of inhaled steroids on RV and total lung capacity (TLC) in COPD patients can be found. However, in the 12-week double-blind study of John et al. (27), it was demonstrated that beclomethasone did not affect FEV level in COPD patients, but decreased the RV/TLC percentage, which is an indicator of hyperinflation, from $144 \%$ to $131 \%$. On the other hand, in our study, it was found that the use of inhaled steroids did not have significant effects on RV and TLC.

Rochester and Braun (28) found lower PImax (MIP) and PEmax (MEP) values in COPD patients than in normal patients. The decreases in PImax and in PEmax were attributed to hyperinflation and diffuse muscle weakness (low body mass index, hypokalemia, systemic steroid use, hypoxemia), respectively. In patients with COPD, the effect of inhaled corticosteroids on respiratory muscle strength is unclear. However, in a study by Jardim et al. (29), it was detected that the use of inhaled flunisolide in healthy individuals did not have an acute or clinical effect on peripheral or respiratory muscle strength. Similarly, the use of inhaled steroids was found to have no positive or negative effect on respiratory muscle strength in our study.

In patients with COPD, RAW increases because of various reasons. In a literature review, we found no study investigating the effect of inhaled steroids on RAW in COPD patients. However, in a long-term study, it was reported that a significant decrease was observed in bronchial hyperactivity and RAW values in asthma patients using low-dose $(200 \mu \mathrm{g})$ budesonide for 3 years, GAW values increased, and thus, the occurrence of an acute attack was prevented through improved pulmonary functions (30). Our study showed that the addition of inhaled steroids to bronchodilator treatment had no significant effect on airway resistance in COPD patients. To obtain an effect, it may be necessary to lengthen the study period.

In our literature review, no study on the effects of inhaled steroids on FFM in COPD patients was encountered. However, in a study conducted on female patients diagnosed with asthmatic bronchiole and receiving steroid therapy, it was observed that systemic steroid treatment caused FFM loss, particularly in the lower extremities; however, inhaled steroids led to no change (31). In another study conducted with 64 patients with COPD, FFM loss in COPD patients was found to be associated with impaired lung functions, continuance of smoking, and frequent exacerbations; a decrease in FFM was observed in patients continuing to use systemic steroids (32). On the other hand, in our study, no statistically significant difference was observed in terms of FFM in patients using inhaled steroids for 3 months compared with the control group. Despite the short study period, it can be concluded that inhaled steroids did not have any negative effect on FFM because their systemic absorptions were low according to the results, contrary to systemic steroids.

In cases with COPD, the quality of life is impaired in time. The effects of regular treatment with inhaled corticosteroids on the quality of life are controversial. In a randomized controlled study conducted by Bourbeau et al. (33), patients were randomly divided into two groups after having received oral prednisolone therapy for 2 weeks. One group was administered a placebo for 6 months, and the other group was administered $1600 \mu \mathrm{g}$ budesonide a day. No significant difference was observed with respect to the quality of life. In addition, Lung Health Study II demonstrated that inhaled corticosteroids did not have any effect on the quality of life measurements (34).

Contrary to these studies, it was reported in many studies that the addition of inhaled steroids to a long-acting bronchodilator agent improved the quality of life much more than the separate use of these drugs (35-39). In long-term studies conducted with large series, which are mentioned above, it was revealed that the use of inhaled steroids affected the quality of life positively in patients with COPD $(26,27)$. Similarly, our study showed that the addition of inhaled steroids to long-acting bronchodilator therapy affected the quality of life questionnaire scores in a positive way. The occurrence of an improvement in the quality of life without any recovery in pulmonary functions shows that the respiration survey reflects some other features besides airway obstruction.

The evaluation of exercise capacity, in COPD patients is very important. In the literature, there are contradictory results related to the effect of inhaled steroids on 6MWT. No statistically significant difference was found between the use of inhaled steroids and a placebo and 6MWT results in a group of patients with severe irreversible airway obstruction (40). In another study conducted by Yıldırım (41), a group of COPD patients receiving long-acting bronchodilator therapy was compared to another group of COPD patients receiving inhaled steroids+long-acting bronchodilator therapy. The increase in walking distance at the end of 6 weeks was found to be significantly higher in the group using inhaled steroids. In a similar study 
by Paggiaro et al. (22), the walking distance was reported to be longer in patients administered fluticasone propionate than in patients administered a placebo. As in the last two studies mentioned above, a statistically significant increase in walking distance was observed in the patient group using budesonide+tiotropium compared with those using only tiotropium in our study; it was thought that this might be associated with the reduction in the patients' daily symptoms and subjective complaints.

A meta-analysis conducted recently revealed that the combination of inhaled corticosteroids and long-acting $\beta_{2}$ agonists improved pulmonary functions and the quality of life scores much more than a single long-acting $\beta_{2}$ agonist agent (42). However, there are a few studies comparing the efficiencies of inhaled corticosteroids/long-acting anticholinergic combination and a single long-acting anticholinergic agent in patients with COPD. In one of these literature studies, it was reported that an improvement was observed in the quality of life and exercise capacity, of the patients after 6 weeks of treatment, and changes in the $\mathrm{FEV}_{1}$ values were found to be insignificant compared with the group using single tiotropium. Moreover, it was suggested in this study that the efficiency of budesonide+tiotropium could be increased when used at a low dose (39).

\section{CONCLUSION}

Our study revealed that the addition of inhaled steroids to tiotropium, which is a long-acting inhaled anticholinergic, did not cause significant effects on pulmonary functions, but positively affected the quality of life and exercise capacity. This study is important because it is one of only a few studies using tiotropium and an inhaled steroid agent in the literature. However, we must accept that it has some limitations. Because our study was conducted on a small patient group in a single center, our findings cannot be generalized for the whole population. Moreover, the study period is shorter than many comprehensive studies. Therefore, it should be supported by further multi-centered and long-time studies.

Ethics Committee Approval: Ethics committee approval was received for this study from the ethics committee of Firat University.

Informed Consent: Written informed consent was obtained from patients who participated in this study.

Peer-review: Externally peer-reviewed.

Author Contributions: All authors contributed equally during the preparation of this manuscript.

Conflict of Interest: No conflict of interest was declared by the authors.

Financial Disclosure: The authors declared that this study has received no financial support.

\section{REFERENCES}

1. Global Strategy for the Diagnosis, Management and Prevention of Chronic Obstructive Pulmonary Disease, Revised 2011. www.goldcopd.org.

2. Pauwels RA, Buist AS, Calverley PM, Jenkins CR, Hurd SS, GOLD Scientific Commitee. Global strategy for the diagnosis, management, and prevention of chronic obstructive pulmonary disease. NHLBI/WHO global initiative for chronic obstructive lung disease (GOLD) workshop summary. Am J Respir Crit Care Med 2001; 163: 1256-76. [CrossRef]

3. Donohue JF, van Noord JA, Bateman ED, Langley SJ, Lee A, Witek TJ Jr, et al. A 6-month, placebo-controlled study comparing lung function and health status changes in COPD patients treated with tiotropium or salmeterol. Chest 2002; 122: 47-55. [CrossRef]
4. Vincken W, van Noord JA, Greefhorst AP, Bantje TA, Kesten S, Korducki L, et al. Improved health outcomes in patients with COPD during 1 yr's treatment with tiotropium. Eur Respir J 2002; 19: 209-16. [CrossRef]

5. Casaburi R, Mahler DA, Jones PW, Wanner A, San PG, ZuWallack RL, et al. A long-term evaluation of once-daily inhaled tiotropium in chronic obstructive pulmonary disease. Eur Respir J 2002; 19: 217-24. [CrossRef]

6. van Noord JA, Bantje TA, Eland ME, Korducki L, Cornelissen PJ. A randomised controlled comparison of tiotropium and ipratropiumin the treatment of chronic obstructive pulmonary disease. The Dutch Tiotropium Study Group. Thorax 2000; 55: 289-94. [CrossRef]

7. Ferrer M, Alonso J, Morera J, Marrades RM, Khalaf A, Aguar MC, et al. Chronic obstructive pulmonary disease stage and health-related quality of life. The quality of life of chronic obstructive pulmonary disease study group. Ann Intern Med 1997; 127: 1072-9. [CrossRef]

8. Calverley PMA, Pearson MG. Clinical and laboratuary assesment. Calverley PMA, Mac nee W, Pride NB, Rennard SI (Eds.). Chronic obstructive pulmonary disease 2nd.Ed. London, Arnold, 2003: 282-309.

9. Sterk PJ, Fabbri LM, Quanjer PH, Cockcroft DW, O'Byrne PM, Anderson SD, et al. Airway responsiveness. Standardized challenge testing with pharmacological, physical and sensitizing stimuli in adults. Report Working Party Standardization of Lung Function Tests, European Community for Steel and Coal. Official Statement of the European Respiratory Society. Eur Respir J 1993; 16: 53-83. [CrossRef]

10. Quanjer PH, Tammeling GJ, Cotes JE, Pedersen OF, Peslin R, Yernault JC. Lung volumes and forced ventilatory flows. Eur Respir J 1993; 6 (Suppl 16): 5-40. [CrossRef]

11. American Thoracic Society/European Respiratory Society. ATS/ERS Statement on respiratory muscle testing. Am J Respir Crit Care Med 2002; 166: 518-624. [CrossRef]

12. Windisch W, Hennings E, Sorichter S, Hamm H, Criée CP. Peak or plateau maximal inspiratory mouth pressure: which is best? Eur Respir J 2004; 23 : 708-13. [CrossRef]

13. Jones PW, Quirk FH, Baveystock CM, Littlejohns P. A self-complete measure of health status for chronic airflow limitation. The St. George's respiratory Questionnaire. Am Rev Respir Dis 1992; 145: 1321-7. [CrossRef]

14. ATS Committee on Proficiency Standards for Clinical Pulmonary Function Laboratories. ATS Statement: guidelines for the six minute-walk test. Am J Respir Crit Care Med 2002; 166: 111-7. [CrossRef]

15. Karner C, Chong J, Poole P. Tiotropium versus placebo for chronic obstructive pulmonary disease. Cochrane Database Syst Rev 2012; 7: CD009285. [CrossRef]

16. Chong J, Karner C, Poole P. Tiotropium versus long-acting beta-agonists for stable chronic obstructive pulmonary disease. Cochrane Database Syst Rev 2012; 9: CD009157. [CrossRef]

17. Watson A, Lim TK, Joyce H, Pride NB. Failure of inhaled corticosteroids to modify bronchoconstrictor or bronchodilator responsiveness in middle-aged smokers with mild airflow obstruction. Chest 1992; 101: 350-5. [CrossRef]

18. Kertjens HA, Brand PL, Hughes MD, Robinson NJ, Postma DS, Sluiter HJ, et al. A comparison of bronchodilator therapy with or without inhaled corticosteroid therapy for obstructive airways disease. Dutch chronic non-spesific lung disease study group. N Engl J Med 1992; 327: 1413-9. [CrossRef]

19. Dompeling E, Van Schayck CP, Molema J, Folgering H, van Grunsven PM, van Weel $C$. Inhaled beclomethazone improves the course of asthma and COPD. Eur Respir J 1992; 5: 945-52.

20. Cazzola M, Matera MG, Pauwels R. Corticosteroids in COPD. Celli BR (Ed.). Pharmacotherapy in Chronic Obstructive Pulmonary Disease. 1. baskı, New york: Merkel Dekker, 2004: 265-98.

21. Thompson WH, Carvalho P, Souza JP, Charan NB. Controlled trial of inhaled fluticasone propionate in moderate to severe COPD. Lung 2002; 180: 191-201. [CrossRef]

22. Paggiaro PL, Dahle R, Bakran I, Frith L, Hollingworth K, Efthimiou J. Multicentre randomised placebo-controlled trial of inhaled fluticasone propio- 
nate in patients with chronic obstructive pulmonary disease. International COPD Study Group. Lancet 1998; 351: 773-80. [CrossRef]

23. Pauwels RA, Löfdahl CG, Laitinen LA, Schouten JP, Postma DS, Pride NB, et al. Long term treatment with inhaled budesonide in persons with mild in chronic obstructive pulmonary disease who continue smoking. N Engl J Med 1999; 340: 1948-53. [CrossRef]

24. Vestbo J, Sørensen T, Lange P, Brix A, Torre P, Viskum K. Long-term effect of inhaled budesonide in mild and moderate chronic obstructive pulmonary disease: a randomised controlled trial. Lancet 1999; 353: 1819-23. [CrossRef]

25. Burge PS, Calverley PM, Jones PW, Spencer S, Anderson JA, Maslen TK. Randomised, double blind, placebo controlled study of fluticasone propionate in patients with moderate to severe obstructive pulmonary disease: the ISOLDE trial. BMJ 2000; 320: 1297-303. [CrossRef]

26. Celli BR, Thomas NE, Anderson JA, Ferguson GT, Jenkins CR, Jones PW, et al. Effect of pharmacotherapy on rate of decline of lung function in chronic obstructive pulmonary disease: results from the TORCH study. Am J Respir Crit Care Med 2008; 178: 332-8. [CrossRef]

27. John M, Bosse S, Oltmanns U, Schumacher A, Witt C. Effects of inhaled HFA beclomethasone on pulmonary function and symptoms in patients with chronic obstructive pulmonary disease. Respir Med 2005; 99: 1418-24. [CrossRef]

28. Rochester DF, Braun NM. Determinants of maximal inspiratory pressure in chronic obstructive pulmonary disease. Am Rev Respir Dis 1985; 132: 42-7.

29. Jarim JR, Camelier A, Dal Corso S, Rodriques JE. Strength and endurance of the respiratory and handgrip muscles after the use of flusinolide in normal subjects. Respir Med 2007; 101: 1594-9. [CrossRef]

30. Weng JL, Zheng YS, Ma QF. The long term effect of small dose budesonide turbuhaler in mild bronchial asthma. Zhonghua Jie He He Hu Xi Za Zhi 2005; 28: 88-92.

31. Targowski T, Frank-Piskorska A, Jahnz-Rózyk K, Plusa T. Influence of chronic glucocorticosteroid therapy on fat free mass in women with severe bronchial asthma. Pol Merkur Lekarski 2004; 17: 567-70.

32. Hopkinson NS, Tennant RC, Dayer MJ, Swallow EB, Hansel TT, Moxham J, et al. A prospective study of decline in fat free mass and skeletal muscle strength in chronic obstructive pulmonary disease. Respir Res 2007; 8: 25. [CrossRef]
33. Bourbeau J, Rouleau MY, Boucher S. Randomised controlled trial of inhaled corticosteroids in patients with chronic obstructive pulmonary disease. Thorax 1998; 53: 477-82. [CrossRef]

34. Lung Health Study Research Group. Effect of inhaled triamcinolone on the decline in pulmonary function in chronic obstructive pulmonary disease. N Engl J Med 2000; 343: 1902-9. [CrossRef]

35. Calverley PM, Boonsawat W, Cseke Z, Zhong N, Peterson S, Olsson H. Maintenance therapy with budesonide and formoterol in chronic obstructive pulmonary disease. Eur Respir J 2003; 22: 912-9. [CrossRef]

36. Calverley P, Pauwels R, Vestbo J, Jones P, Pride N, Gulsvik A, et al. Combined salmeterol and fluticasone in the treatment of chronic obstructive pulmonary disease: a randomised controlled trial. Lancet 2003; 361: 449-56. [CrossRef]

37. Szafranski W, Cukier A, Ramirez A, Menga G, Sansores R, Nahabedian S, et al. Efficacy and safety of budesonide/formoterol in the management of chronic obstructive pulmonary disease. Eur Respir J 2003; 21: 74-81. [CrossRef]

38. Hanania NA, Darken P, Horstman D, Reisner C, Lee B, Davis S, et al. The efficacy and safety of fluticasone propionate ( $250 \mathrm{microg}) /$ salmeterol (50 microg) combined in the Diskus inhaler for the treatment of COPD. Chest 2003; 124: 834-43. [CrossRef]

39. Um SW, Yoo CG, Kim YW, Han SK, Shim YS. The combination of tiotropium and budesonide in the treatment of chronic obstructive pulmonary disease. J Korean Med Sci 2007; 22: 839-45. [CrossRef]

40. O'Brien A, Russo-Magno P, Karki A, Hiranniramol S, Hardin M, Kaszuba M, et al. Effects of withdrawal of inhaled steroids in men with severe irreversible airflow obstruction. Am J Respir Crit Care Med 2001; 164: 365-71. [CrossRef]

41. Yıldırım N. Stabil KOAH'da uzun süreli inhaler kortikosteroid tedavi. Kronik Obstrüktif Akciğer Hastalığı (KOAH). Umut S, Yıldııım N (Eds.). İstanbul Üniversitesi Cerrahpaşa Tıp Fakültesi Göğüs Hastalıkları Anabilim dalı Kitap Dizisi-4. İstanbul, Turgut Yayıncılık 2005: 126-36.

42. Nannini $\sqcup$, Lasserson TJ, Poole P. Combined corticosteroid and long-acting beta(2)-agonist in one inhaler versus long-acting beta(2)-agonists for chronic obstructive pulmonary disease. Cochrane Database Syst Rev 2012; 9: CD006829. 